\title{
Metabasites from the KTB Oberpfalz target area, Bavaria-geochemical characteristics and examples of mobile behaviour of "immobile" elements
}

\author{
U. SCHÜSSLER, P. RICHTER and M. OKRUSCH \\ Mineralogisches Institut, Universität Würzburg, Am Hubland, D-8700 Würzburg (F.R.G.) \\ (Received August 3, 1987; revised version accepted November 15, 1987)
}

\begin{abstract}
Schüssler, U., Richter, P. and Okrusch, M., 1989. Metabasites from the KTB Oberpfalz target area, Bavaria-geochemical characteristics and examples of mobile behaviour of "immobile" elements. In: R. Meissner and D. Gebauer (Editors), The Evolution of the European Continental Crust: Deep Drilling, Geophysics, Geology and Geochemistry. Tectonophysics, 157: 135-148.

Major-, trace- and rare-earth element chemistry studies of metabasite intercalations within different tectonic units of the East Bavarian crystalline basement leads to the following geochemical classification: The flaser amphibolites of the Erbendorf-Vohenstrauss Zone (ZEV) exhibit an enriched, E-MORB- or intraplate-like tholeiitic character, whereas the schistose and striped amphibolites of the ZEV and of the Tirschenreuth-Mähring Zone show N-MORB compositions. The metagabbros of the ZEV are transitional between these two types. The metabasites of the Erbendorf Greenschist Zone are similar to modern island-arc basalts (tholeiitic to calc-alkaline). The Fichtelgebirge crystalline complex contains amphibolites of enriched tholeiitic to alkaline, i.e., intraplate character.

In most of the investigated metabasites, a post-basaltic/post-gabbroic mobilization of the trace elements cannot be recognized. An exception is $\mathrm{Ba}$ which is generally enriched. This may be due to pre-metamorphic hydrothermal alteration processes and/or to a synmetamorphic chemical exchange with adjacent metasediments. The contact-metamorphic overprint of some flaser amphibolites from the ZEV by the intrusion of the Variscan Falkenberg granite led to enrichment in $\mathrm{Li}, \mathrm{Rb}, \mathrm{K}$ and $\mathrm{W}$, a simultaneous depletion in $\mathrm{Ca}, \mathrm{Sr}, \mathrm{Cr}$ and $\mathrm{Ni}$, and a decrease in the $\mathrm{K} / \mathrm{Rb}$ ratio. $\mathrm{Nb}$, $\mathrm{Ce}, \mathrm{P}, \mathrm{Zr}, \mathrm{Ti}$ and $\mathrm{V}$ scatter in a much wider range than in the unaffected flaser amphibolites, although with no clear tendency for enrichment or depletion. A mobilization of P and the LREE's in some schistose and striped amphibolites of the ZEV and in the contact-metamorphosed flaser amphibolites is presumably a result of post-granitic hydrothermal alteration which is indicated by enrichment of As as a pathfinder element.
\end{abstract}

\section{Introduction}

Since the classic work of Pearce and Cann (1973) trace-element characteristics of basaltic suites have frequently been used as indicators of the geotectonic settings of these suites. Moreover, metamorphic petrologists have attempted to apply the trace-element contents of metabasites as fingerprints for the palaeoenvironment in which their basaltic protoliths were emplaced. Such an approach can only be successful if the trace ele- ments used for discrimination are immobile during post-basaltic pre-, syn- or post-metamorphic alteration processes.

Our investigations in the target area of the German Continental Deep Drilling Program (KTB) revealed distinct geochemical characteristics for various metabasite types which may reflect different palaeoenvironments and may provide additional constraints for geotectonic reconstructions. Additionally, we found compelling evidence for the mobile behaviour of certain trace- and 


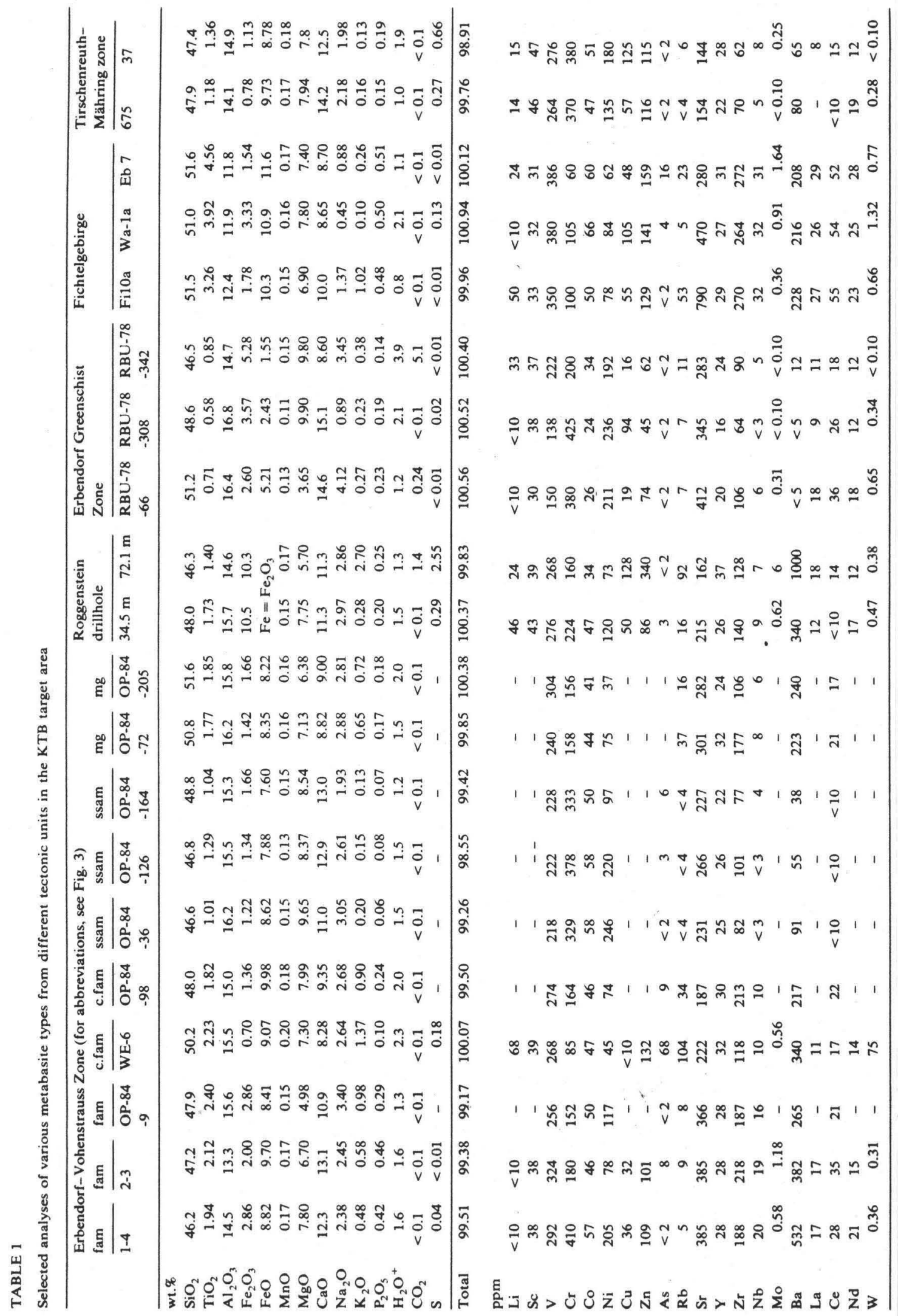

rare-earth elements which, in special cases, are commonly regarded as immobile.

\section{Geological setting}

In the KTB target area around Erbendorf, Bavaria, metabasites play an important role in the geology. They form members of two different tectonic units, the Erbendorf-Vohenstrauss Zone (ZEV) and the Erbendorf Greenschist Zone (EGZ) (Figs. 1 and 2). According to the new geotectonic concepts developed during the KTB pre-site studies (Weber and Vollbrecht, 1986), both units form part of a nappe pile which covers the suture zone between the presumably autochthonous Saxothuringian and Moldanubian realms. This view is supported by the results of the recent deep reflection seismic DEKORP 4 and related profiles (Schmoll, in Weber and Vollbrecht, 1986).

The Erbendorf-Vohenstrauss Zone (ZEV) is regarded as the upper nappe unit. It consists mainly

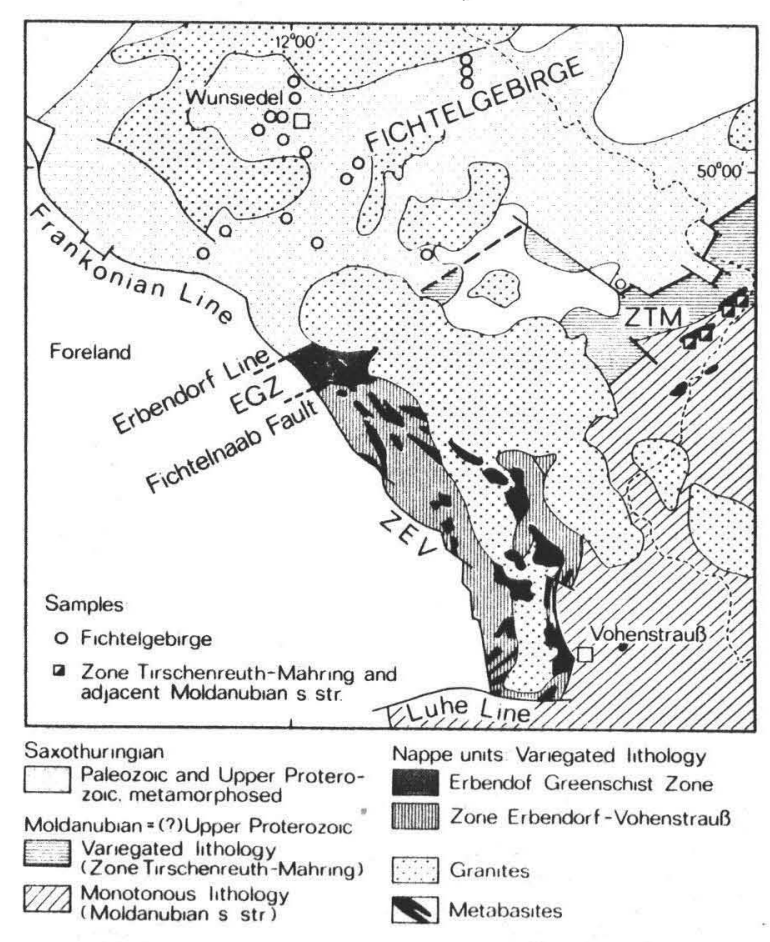

Fig. 1. Geological situation of the northeastern Bavarian crystalline basement (based on the geological map of Bavaria), with sample localities in the Fichtelgebirge area (circles), in the Tirschenreuth-Mähring Zone and in the adjacent Moldanubian sensu stricto (half-filled squares).

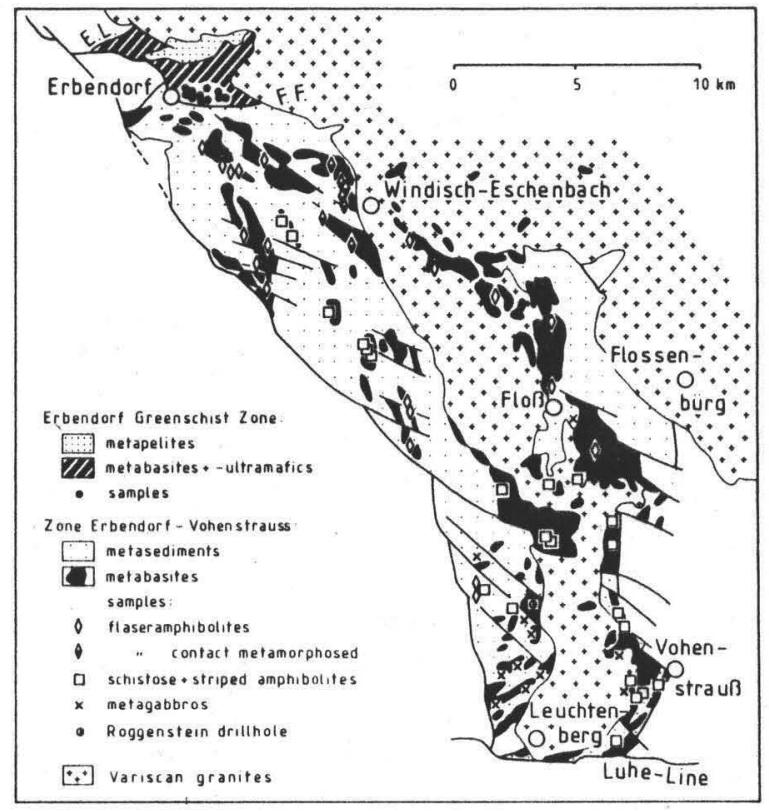

Fig. 2. Regional distribution of metabasites within the Erbendorf-Vohenstrauss Zone and the Erbendorf Greenschist Zone (based on the geological map of Bayreuth), with sample localities. E.L. - Erbendorf Line; F.F.-Fichtelnaab Fault.

of metasediments and various types of amphibolites, with metagabbros and minor intercalations of orthogneisses and ultramafics.

Metamorphism took place under medium-pressure amphibolite-facies conditions and is dated at about 380 Ma (Teufel, 1988; Schüssler et al., 1986). Older eclogitic relics are rarely present (Voll, 1960; Busch, 1970). Parts of the metamorphic sequence in the ZEV underwent contact-metamorphic overprinting by the Leuchtenberg and the Falkenberg granites (Voll, 1960; Okrusch, 1969; Schüssler, 1987) which intruded about 321 and 311 m.y. ago, respectively (Köhler and MüllerSohnius, 1976; Wendt et al., 1986).

The Erbendorf Greenschist Zone (EGZ), regarded as the lower nappe unit, consists predominantly of metabasites and serpentinites, together with subordinate metasediments. They were initially metamorphosed under conditions of the lowest amphibolite facies, but underwent a later retrograde metamorphism under greenschist-facies conditions. In addition, a contact-metamorphic overprint by the Falkenberg and the $306 \mathrm{Ma}$ old Steinwald granite (Wendt, pers. commun., 1987) affected parts of the EGZ (Matthes, 1951). 
Minor metabasite intercalations are recorded in the Fichtelgebirge and in the TirschenreuthMähring Zone (ZTM):

The Fichtelgebirge crystalline complex, part of the Saxothuringian, forms an anticlinal structure between the Erbendorf Line in the south and the southern margin of the allochthonous Münchberg complex in the north. Part of this zone is characterized by a variegated lithology with numerous intercalations of marbles, calcsilicate rocks and minor metabasites ("Bunte Gruppe" of Stettner, 1975, 1980). There are, however, transitions to more monotonous lithology with a predominance of pelitic to psammitic metasediments. The sequence underwent low-pressure metamorphism ranging from greenschist to amphibolite facies (Mielke et al., 1979). Mineral relics of an older medium-pressure event were recently recognized by Lenz et al. (in prep.). The metamorphic assemblages were partly overprinted by the $320-285$

TABLE 2

Rare-earth element contents (ppm) of the various metabasite types

\begin{tabular}{|c|c|c|c|c|c|c|c|c|c|c|c|c|c|c|c|}
\hline & \multicolumn{8}{|c|}{ Schistose + striped amphibolites (ZEV) } & \multicolumn{7}{|c|}{ Flaser amphibolites (ZEV) } \\
\hline & \multicolumn{8}{|l|}{ OP-84 } & \multirow[t]{2}{*}{$1-2$} & \multirow[t]{2}{*}{$1-3$} & \multirow[t]{2}{*}{$1-4$} & \multirow[t]{2}{*}{$1-5$} & \multirow[t]{2}{*}{$2-3$} & \multirow[t]{2}{*}{$2-5$} & \multirow[t]{2}{*}{$2-7$} \\
\hline & -27 & -36 & -49 & -55 & -67 & -126 & -164 & -168 & & & & & & & \\
\hline $\mathrm{La}$ & 5.6 & 2.8 & 0.5 & 1.3 & 1.8 & 3.3 & 3.0 & 3.7 & 19 & 15 & 17 & 14 & 16 & 9.5 & 16 \\
\hline $\mathrm{Ce}$ & 16 & 8.6 & 2.5 & 4.9 & 6.4 & 11 & 8.6 & 12 & 46 & 38 & 41 & 36 & 41 & 29 & 38 \\
\hline $\mathrm{Pr}$ & 2.9 & 1.3 & 0.9 & 0.9 & 1.7 & 2.1 & 1.6 & 2.3 & 6.5 & 5.3 & 6.1 & 5.9 & 5.4 & 4.7 & 6.2 \\
\hline $\mathrm{Nd}$ & 13 & 6.9 & 4.6 & 5.1 & 7.3 & 9.3 & 6.8 & 9.9 & 24 & 22 & 23 & 22 & 23 & 19 & 22 \\
\hline $\mathrm{Sm}$ & 4.2 & 2.4 & 2.0 & 1.9 & 2.9 & 3.0 & 2.4 & 3.3 & 6.0 & 5.4 & 5.2 & 5.8 & 5.9 & 5.4 & 5.4 \\
\hline $\mathrm{Eu}$ & 1.34 & 1.02 & 0.86 & 0.79 & 1.09 & 1.16 & 0.97 & 1.13 & 1.83 & 1.69 & 2.06 & 2.10 & 2.05 & 1.81 & 1.99 \\
\hline Gd & 5.2 & 3.3 & 3.0 & 3.0 & 4.3 & 3.7 & 3.4 & 4.4 & 5.3 & 6.0 & 6.1 & 7.4 & 6.0 & 5.9 & 6.3 \\
\hline $\mathrm{Tb}$ & 0.99 & 0.62 & 0.65 & 0.56 & 0.87 & 0.66 & 0.70 & 0.90 & 0.92 & 1.02 & 0.98 & 1.26 & 1.07 & 1.08 & 1.04 \\
\hline Dy & 5.9 & 4.0 & 3.8 & 3.7 & 5.5 & 4.2 & 4.4 & 5.6 & 5.4 & 5.8 & 6.0 & 7.6 & 6.3 & 6.0 & 5.9 \\
\hline Ho & 1.21 & 0.84 & 0.78 & 0.76 & 1.17 & 0.86 & 0.94 & 1.20 & 1.02 & 1.13 & 1.17 & 1.44 & 1.23 & 1.17 & 1.13 \\
\hline Er & 3.9 & 2.8 & 2.7 & 2.6 & 3.8 & 2.8 & 3.1 & 3.9 & 3.2 & 3.4 & 3.5 & 4.6 & 3.7 & 3.7 & 3.4 \\
\hline $\mathrm{Tm}$ & 0.49 & 0.36 & 0.36 & 0.36 & 0.52 & 0.35 & 0.43 & 0.52 & 0.38 & 0.41 & 0.41 & 0.56 & 0.44 & 0.42 & 0.41 \\
\hline $\mathrm{Yb}$ & 3.2 & 2.5 & 2.3 & 2.3 & 3.3 & 2.3 & 2.8 & 3.4 & 2.8 & 3.0 & 3.0 & 3.9 & 3.2 & 3.1 & 2.9 \\
\hline \multirow[t]{5}{*}{$\mathrm{Lu}$} & 0.46 & 0.37 & 0.33 & 0.34 & 0.47 & 0.32 & 0.41 & 0.49 & 0.41 & 0.42 & 0.42 & 0.55 & 0.46 & 0.44 & 0.40 \\
\hline & \multirow{2}{*}{\multicolumn{6}{|c|}{$\begin{array}{l}\text { Flaser amphibolites contact } \\
\text { metamorphosed (ZEV) }\end{array}$}} & \multicolumn{5}{|c|}{ Erbendorf Greenschist Zone } & \multicolumn{4}{|c|}{ Zone Tirschenreuth-Mähring } \\
\hline & & & & & & & \multicolumn{2}{|c|}{ RBU-78 } & \multirow{3}{*}{-306} & \multirow{3}{*}{-308} & \multirow{3}{*}{-342} & \multirow{3}{*}{$\begin{array}{l}\text { OP-84 } \\
-244\end{array}$} & \multirow[t]{3}{*}{37} & \multirow[t]{3}{*}{660} & \multirow[t]{3}{*}{675} \\
\hline & OP-84 & $2-1$ & $2-12$ & & WE-5 & WE-6 & -65 & -66 & & & & & & & \\
\hline & -98 & & & & & & & & & & & & & & \\
\hline $\mathrm{La}$ & 15 & 12 & 20 & & 31 & 7.7 & 9.4 & 18 & 10 & 13 & 10 & 2.7 & 3.9 & 2.7 & 2.8 \\
\hline $\mathrm{Ce}$ & 38 & 28 & 49 & & 80 & 19 & 22 & 41 & 25 & 30 & 24 & 12 & 12 & 8.7 & 8.9 \\
\hline $\operatorname{Pr}$ & 6.3 & 5.2 & 6.6 & & 14 & 3.0 & 3.0 & 4.2 & 3.4 & 3.9 & 3.2 & 3.2 & 1.7 & 1.6 & 1.3 \\
\hline $\mathrm{Nd}$ & 23 & 19 & 26 & & 51 & 12 & 11 & 18 & 12 & 15 & 12 & 14 & 9.4 & 7.5 & 7.9 \\
\hline $\mathrm{Sm}$ & 6.1 & 5.2 & 6.2 & & 14 & 3.6 & 2.8 & 3.5 & 2.9 & 3.1 & 2.8 & 5.1 & 3.0 & 2.7 & 2.8 \\
\hline $\mathrm{Eu}$ & 1.81 & 1.52 & 1.9 & & 4.14 & 1.16 & 0.90 & 1.03 & 0.95 & 0.93 & 1.09 & 1.62 & 1.09 & 0.98 & 1.03 \\
\hline Gd & 6.3 & 5.9 & 6.0 & & 15 & 4.1 & 3.0 & 3.2 & 3.0 & 2.8 & 2.9 & 6.3 & 4.2 & 3.9 & 3.9 \\
\hline $\mathrm{Tb}$ & 1.18 & 1.04 & 0.9 & & 2.55 & 0.80 & 0.56 & 0.54 & 0.54 & 0.47 & 0.62 & 1.31 & 0.78 & 0.77 & 0.80 \\
\hline Dy & 6.7 & 6.5 & 5.2 & & 15 & 4.7 & 3.3 & 3.0 & 3.3 & 2.8 & 3.2 & 7.8 & 4.8 & 4.9 & 4.9 \\
\hline Ho & 1.36 & 1.28 & 1.0 & 03 & 2.81 & 0.96 & 0.69 & 0.58 & 0.67 & 0.53 & 0.67 & 1.80 & 1.03 & 1.09 & 1.01 \\
\hline Er & 4.3 & 3.9 & 3.1 & & 8.7 & 3.2 & 2.2 & 1.8 & 2.1 & 1.6 & 2.2 & 5.4 & 3.4 & 3.7 & 3.4 \\
\hline $\mathrm{Tm}$ & 0.54 & 0.48 & 0.3 & 35 & 0.98 & 0.42 & 0.27 & 0.22 & 0.26 & - & 0.27 & 0.77 & 0.42 & 0.48 & 0.46 \\
\hline $\mathrm{Yb}$ & 3.7 & 3.4 & 2.8 & & 6.9 & 2.8 & 2.0 & 1.7 & 1.9 & 1.4 & 1.9 & 4.9 & 2.9 & 3.4 & 3.0 \\
\hline $\mathrm{Lu}$ & 0.54 & 0.48 & 0.4 & 41 & 1.04 & 0.41 & 0.29 & 0.25 & 0.27 & 0.20 & 0.27 & 0.72 & 0.43 & 0.50 & 0.43 \\
\hline
\end{tabular}

ZEV = Erbendorf-Vohenstrauss Zone. 
Ma old Fichtelgebirge granites (e.g., Besang et al., 1976).

The Tirschenreuth-Mähring Zone (ZTM) forms a unit transitional between the Saxothuringian and the Moldanubian and was formed by lowpressure metamorphic overprint under greenschistto amphibolite facies conditions (Schreyer, 1966; Blümel and Wagener-Lohse in Weber and Vollbrecht, 1986). The lithology of the ZTM is less variegated than that of the Fichtelgebirge crystalline complex, but less monotonous than that of the Moldanubian gneisses . (Richter and Stettner, 1983).

\section{Sampling and analytical methods}

The localities of the metabasite samples analyzed are indicated in Figs. 1 and 2. Detailed information on the sample localities and petrography and the complete major- and trace-element analyses are given in Schüssler (1987) and can be obtained from the authors on request. Selected bulk-rock analyses are presented in Table 1, the REE analyses are in Table 2.

The major elements $\mathrm{Si}, \mathrm{Ti}, \mathrm{Al}, \mathrm{Fe}_{\text {tot }}, \mathrm{Mn}, \mathrm{Ca}$ and $\mathrm{K}$ and the trace elements $\mathrm{S}, \mathrm{Sc}, \mathrm{V}, \mathrm{Cr}, \mathrm{Co}, \mathrm{Ni}$, $\mathrm{Cu}, \mathrm{Zn}, \mathrm{As}, \mathrm{Rb}, \mathrm{Sr}, \mathrm{Y}, \mathrm{Zr}, \mathrm{Nb}, \mathrm{Ba}, \mathrm{La}, \mathrm{Ce}$ and $\mathrm{Nd}$ were analyzed by standard XRF, and $\mathrm{Mg}, \mathrm{Na}$ and Li were analyzed by standard AAS methods. Phosphorous and $\mathrm{Fe}$ (II) were analyzed spectrophotometrically, $\mathrm{CO}_{2}$ volumetrically, and $\mathrm{H}_{2} \mathrm{O}^{+}$ by the Penfield method. Tungsten and Mo were determined by liquid-liquid extraction with $\mathrm{Zn}$ dithiol (Richter, 1984). Rare-earth elements were measured by ICP-AES after decomposing the samples in $\mathrm{HF}-\mathrm{HClO}_{4}$ and separating the REE's in chromatographic columns (Erzinger et al., 1984) in the I.G.L., University of Giessen. The Tm values analyzed were not used for interpretations.

\section{Geochemical characteristics}

\section{Schistose and striped amphibolites of the ZEV}

These amphibolites, which are widespread in the southern ZEV (Fig. 2), correspond chemically to subalkaline basalts. In the relevant discrimination diagrams they are clearly different to alkaline

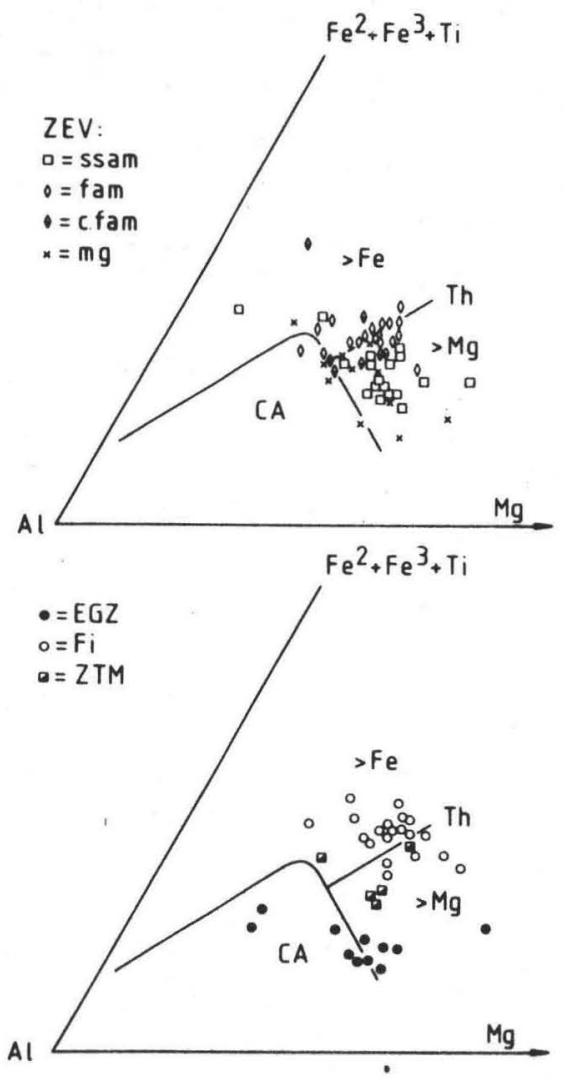

Fig. 3. The position of the samples within the Jensen cation plot (Jensen, 1976). ZEV = Erbendorf-Vohenstrauss Zone; ssam = schistose and striped amphibolites; fam = flaser amphibolites; $\quad$ c. fam $=$ flaser amphibolites, contact metamorphosed; $m g=$ metagabbros; $E G Z=$ Erbendorf Greenschist Zone; $F i=$ Fichtelgebirge; $Z T M=$ Tirschenreuth-Mähring Zone; $\mathrm{Ca}$-calcalkaline basalts; $\mathrm{Th}-$ tholeiites.

basalts. In plots of $\mathrm{FeO}^{*}$ and $\mathrm{TiO}_{2}$ against the $\mathrm{FeO}^{*} / \mathrm{MgO}$ ratio (Miyashiro, 1975) these amphibolites follow the abyssal tholeiite trend. Their Mg-rich tholeiitic character in shown in the Jensen cation plot (Jensen, 1976) (Fig. 3).

Indications of the probable tectonic setting of the tholeiitic protolith are provided by $\mathrm{Ti}-\mathrm{Zr}$ diagrams and $\mathrm{Ti} / \mathrm{Y}-\mathrm{Nb} / \mathrm{Y}$ diagrams (Pearce, 1982) where the schistose and striped amphibolites plot in the mid-ocean ridge basalts field (Fig. 4). MORB-normalized contents of trace elements which are commonly regarded as immobile scatter near the MORB baseline which is typical for N-MORB compositions (Fig. 5a). However, P and $\mathrm{Ce}$ are markedly depleted in some samples, presumably as a result of secondary alteration (see 


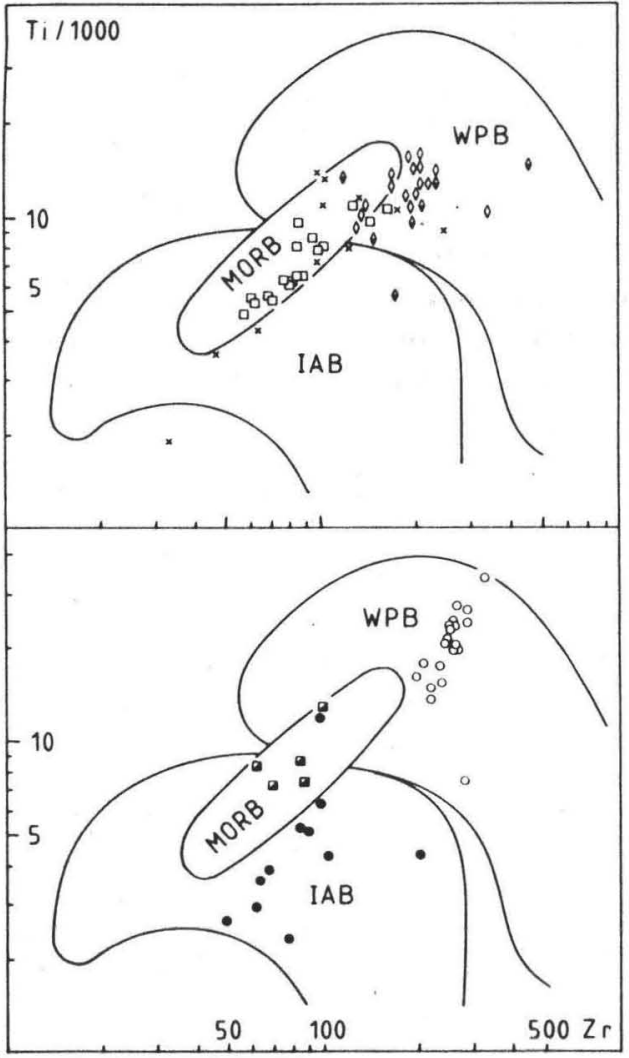

Fig. 4. Ti and $\mathrm{Zr}$ contents (ppm) of the investigated amphibolites and geotectonic interpretation after Pearce (1982). $I A B$-island-arc basalts; $M O R B$-mid-ocean ridge basalts; $W P B$ - within-plate basalts.

below). Niobium is at the detection limit in a few samples.

Total REE contents in the schistose and striped amphibolites range between 25 and $64 \mathrm{ppm}$ (Table 2), $\mathrm{La} / \mathrm{Lu}$ varies between 0.15 and 1.05. Chondrite-normalized REE patterns are flat to LREE depleted, similar to those of fifteen modern basalt samples from normal mid-ocean ridges (Saunders, 1984) (Figs. 6 and 7a). The strong LREE depletion in some samples, parallel to that of $\mathbf{P}$, is probably a secondary effect (see below).

\section{Flaser amphibolites of the ZEV}

Although the garnet-bearing flaser amphibolites prevailing in the northern and central ZEV are subalkaline in their geochemical character, a tendency to more alkaline compositions is indicated. Most samples plot within the subalkaline fields, but some scatter slightly across the borders to the alkaline fields. In the Jensen cation plot (Jensen, 1976), the more Fe-rich tholeiitic character, as compared to the schistose and striped amphibolites of the ZEV, becomes obvious (Fig, 3).

Judging from their trace-element contents, the flaser amphibolites of the ZEV can be compared with modern within-plate basalts, as shown by $\mathrm{Ti} / \mathrm{Y}-\mathrm{Nb} / \mathrm{Y}$ and $\mathrm{Ti}-\mathrm{Zr}$ graphs (Pearce, 1982) (Fig. 4). In contrast to the schistose and striped amphibolites of the ZEV, a clear enrichment of the incompatible elements is seen in MORBnormalized trace-element patterns of the flaser amphibolites from the northern ZEV, which agrees with those of modern basalts from ocean islands or from anomalous mid-ocean ridge segments (EMORB) (Fig. 5b). The same applies to the few flaser amphibolites of the southern ZEV, although their incompatible element contents are somewhat lower than in the northern $\mathrm{ZEV}$.

The flaser amphibolites with total REE contents between 97 and $123 \mathrm{ppm}$ are enriched in LREE's (with $\mathrm{La} / \mathrm{Lu}$ between'2.6 and 4.7). This is typical for modern basalts from ocean islands or from anomalous mid-ocean ridges such as Iceland and the Azores (Saunders, 1984) (Figs. 6 and 7b).

\section{Metagabbros of the ZEV}

The subalkaline, Mg-rich tholeiitic character of the metagabbros from the southwestern ZEV is evident from many plots (e.g., Fig. 3). Trace-element patterns show a slight enrichment of the incompatible elements, agreeing with a transitional position between the schistose and striped amphibolites and the flaser amphibolites (Fig. 5c). Three samples are clearly depleted in incompatible elements and have higher $\mathrm{Cr}$ contents and lower $\mathrm{Fe} / \mathrm{Mg}$ ratios, indicating a less differentiated type of metagabbro. The other samples are comparable with amphibolites alternating with calcsilicate rocks from a drill core near Roggenstein in the ZEV, analyzed by Richter (1983) (Figs. 5c and d).

\section{Metabasites of the EGZ}

Within the EGZ, the predominant striped amphibolites and the minor metagabbros cannot 


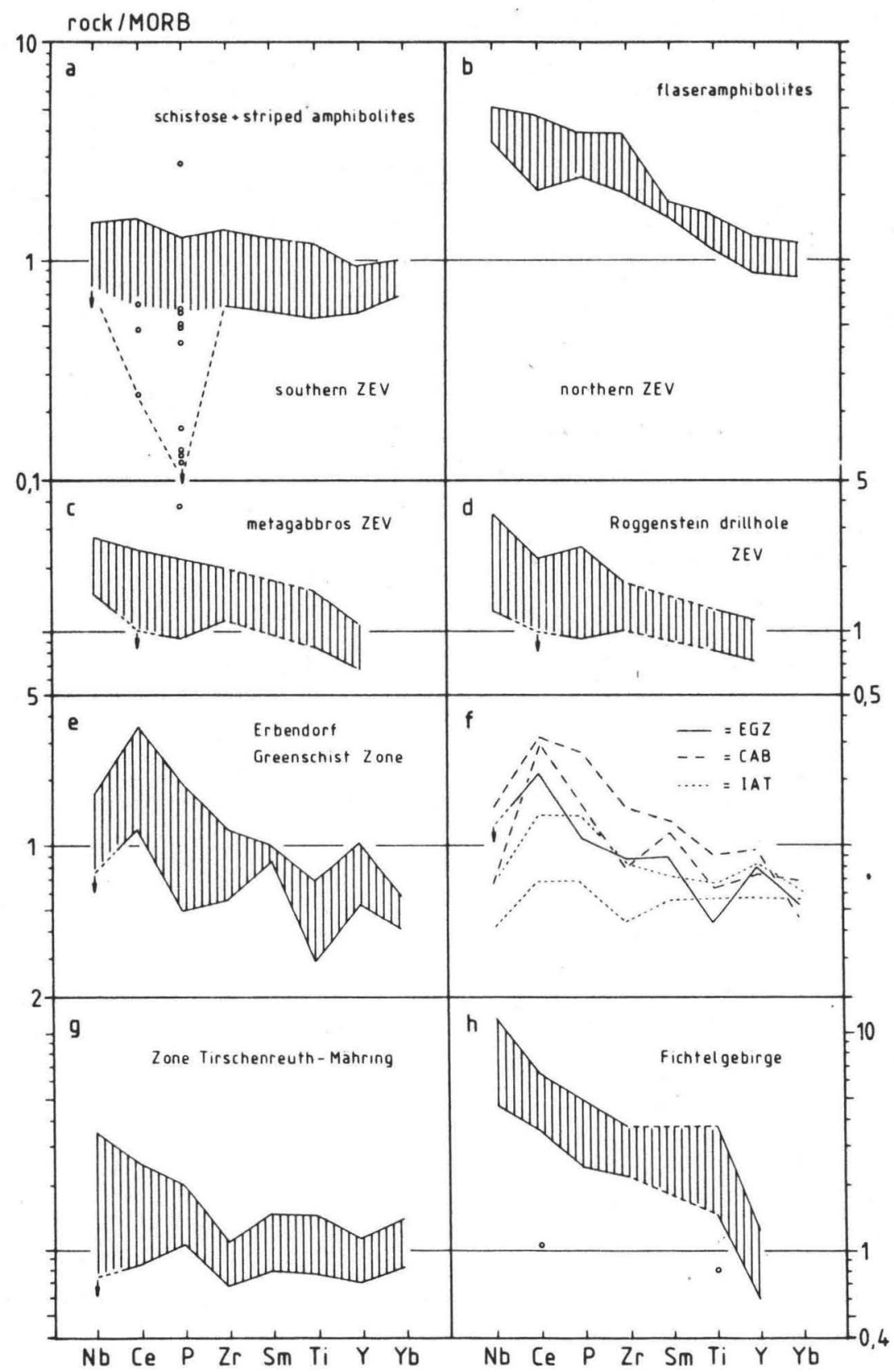

Fig. 5. a-h. Variation of MORB-normalized trace-element contents within the different metabasite types (see also Table 1). Arrows pointing downward indicate values at the detection limit; circles show the position of single samples. MORB-normalization with values from Pearce (1979): Nb, 4 ppm; Ce, 10 ppm; $\mathrm{P}_{2} \mathrm{O}_{5}, 0.12 \% ; \mathrm{Zr}, 90$ ppm; Sm, 3.3 ppm; TiO, $1.5 \% ; \mathrm{Y}, 30$ ppm; Yb, 3.4 ppm. Fig. 5f shows the average trace-element contents of the Erbendorf, Greenschist Zone metabasites (EGZ) compared with island-arc tholeiites $(I A \dot{T})$ and calcalkaline basalts $(C A B)$. Data from Pearce (1982) and Whitford et al. (1979).

be distinguished geochemically. In most diagrams the metabasites of the EGZ form a separate geochemical type which is $\mathrm{Mg}$-rich tholeiitic to calcalkaline in character (Fig. 3). In diagrams showing the tectonic setting of modern basalts the
EGZ metabasites plot along the borderline between mid-ocean ridge and island-arc basalts or in the island-arc basalt field (e.g., Fig. 4).

The MORB-normalized trace-element distribution (Fig. 5e) of the EGZ metabasites clearly 


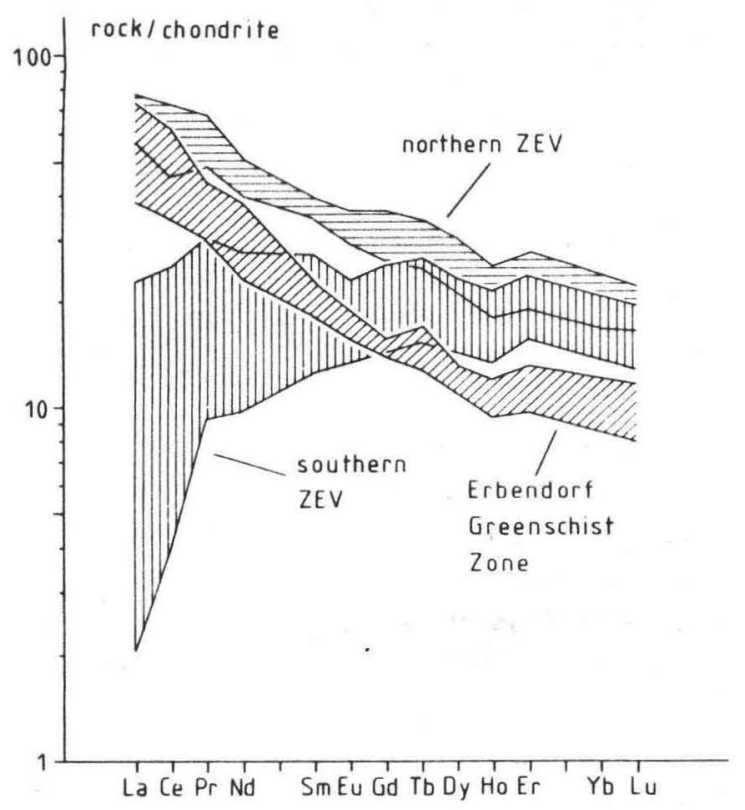

Fig. 6. Variation of chondrite-normalized REE contents within flaser amphibolites of the northern ZEV, the schistose and striped amphibolites of the southern ZEV and the metabasites of the EGZ. Chondrite-normalization with $\mathrm{CI}$-average values (ppm) from Evensen et al. (1978): La, 0.245; Ce, 0.638; Pr, 0.096; Nd, 0.474; Sm, 0.154; Eu, 0.058; Gd, 0.204; Tb, 0.037; Dy, 0.254; Ho, 0.057; Er, 0.166; (Tm, 0.026); Yb, 0.165; Lu, 0.025 .

differs from that of the three ZEV metabasite types. In particular, the low $\mathrm{Nb}$ and $\mathrm{Ti}$ contents in relation to those of the neighbouring elements are conspicuous. This type is well known from modern subduction-bound basalts such as back-arc basin basalts or, more likely, island-arc basalts, especially those with a calcalkaline character (Fig. 5f). The REE patterns are enriched in LREE's (Figs. 6 and 7c). Compared to the ZEV flaser amphibolites which are also enriched in LREE's, the EGZ metabasites display higher $\mathrm{La} / \mathrm{Lu}$ ratios of 3.3-7.3 and lower total REE contents of 61-97 ppm. Modern basalts from converging plate boundaries exhibit a wide range of REE compositions. The EGZ metabasites would correspond to calcalkaline island-arc basalts such as those from the Western Sunda arc (Nicholls et al., 1980) (Fig. 7c), although the REE's are barely different from those of within-plate tholeiites (Fig. 7b). This shows that a classification of (meta-)basalts using REE's alone is not possible. Only a combination of REE's and other discriminating major and trace elements leads to unequivocal results.

Metabasites of the Fichtelgebirge crystalline com-
plex

The Fichtelgebirge amphibolites form a distinct group geochemically transitional between tholeiites and alkaline basalts from within-plate positions or anomalous mid-oceanic ridges (E-MORB). The enrichment of incompatible elements is stronger than in the flaser amphibolites of the northern ZEV (Figs. 4 and 5h).

\section{Amphibolites of the ZTM}

The textural similarities between the ZEV schistose and striped amphibolites and those of the ZTM are matched by nearly identical typical N-MORB geochemistries (Figs. 4 and 5g). The total REE contents of three samples ranges from 42 to $47 \mathrm{ppm}$; $\mathrm{La} / \mathrm{Lu}$ varies between 0.55 and 0.92 . Only the garnet-bearing 'sample (OP-85-244) has markedly higher contents of middle and heavy REE's, whereas the $\mathrm{La}$ and Ce contents are in the same range (Fig. 7d, Table 2).

\section{Element mobility}

For most of the metabasites investigated, the compositional variation within the groups is rather limited. In its major, trace and REE geochemistry, each group is matched by modern basaltic suites, widely distributed in specific geotectonic environments. We regard this as an indication that the basaltic or gabbroic protoliths of the metabasites were not markedly affected by post-basaltic or pre-, syn- or post-metamorphic alterations.

In some cases, however, a post-basaltic mobilization of certain elements is evident: One reason is the contact-metamorphic overprint of metabasites by the intrusion of Variscan granites. On the other hand, some metabasites which are not obviously affected by these intrusions also show indications of element mobility. This may be related to post-granitic hydrothermal mineralizations (Richter and Stettner, 1987). 


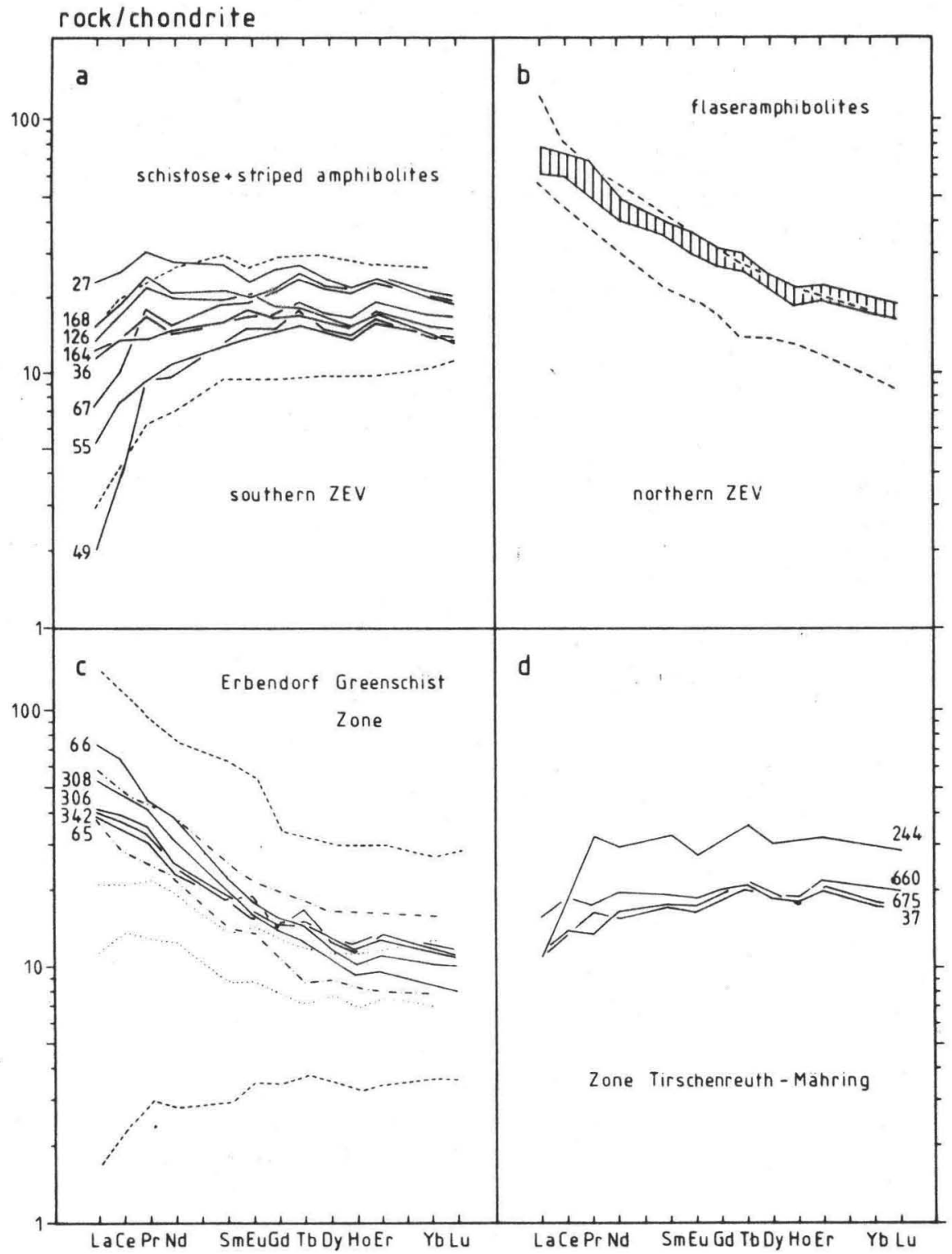

Fig. 7. a. REE patterns of schistose and striped amphibolites of the Erbendorf-Vohenstrauss Zone compared with the REE variation of fifteen N-MORB compositions from mid-ocean ridges of the Atlantic, the Pacific and the Indian Ocean (between dashed lines) Data from Saunders (1984). b. REE variation of six flaser amphibolites (shaded area; without sample 1-5) compared with the variation of five ocean-island tholeiites from the Atlantic Ocean (dashed lines). Data from Saunders (1984). c. REE patterns of metabasites from the Erbendorf Greenschist Zone compared with the variation of REE contents from island arcs and back-arc basins (dashed lines) (data from Cullers and Graf, 1984), with tholeiites (dotted lines), and with calcalkaline basalts (dash-dot lines) from the Western Sunda arc (Nicholls et al., 1980). d. REE patterns of amphibolites from the Tirschenreuth-Mähring Zone are similar to those of the schistose and striped amphibolites from the ZEV.

Element mobility caused by the intrusion of the Variscan granites

The northern ZEV offers the best conditions for studying element mobility caused by contact metamorphism. Here, large NW-SE striking flaser-amphibolite bodies are cut by the Falkenberg granite (Fig. 2). In the contact zone near Windisch-Eschenbach, flaser amphibolites show clear petrographic evidence of a thermal overprint 


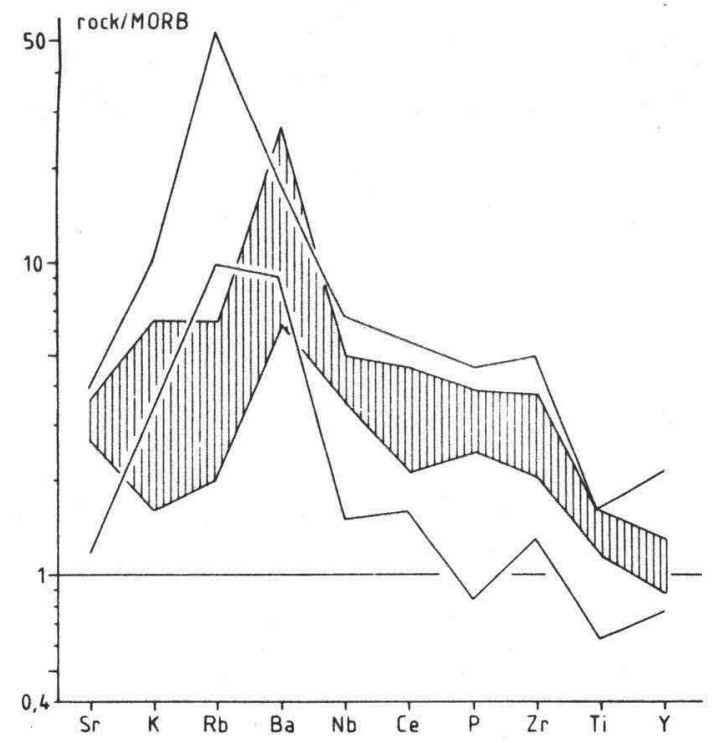

Fig. 8. The variation of the trace-element contents of seven contact-metamorphosed flaser amphibolites near WindischEschenback (light) compared with that of eight unaffected flaser amphibolites (shaded).

and are chemically different from unaffected flaser amphibolites to the north-west (Fig. 8). The overprinted flaser amphibolites are markedly enriched in granitophile elements, especially $\mathrm{Rb}$ and $\mathrm{Li}$, to a lesser degree $\mathrm{K}$, and, as far as analyzed, W. The $\mathrm{K} / \mathrm{Rb}$ ratio decreases from about 600 in unaffected to about 160 in overprinted flaser amphibolites. These changes are typical for the "granitic development" in this area (Richter and Stettner (1987), p. 24). Calcium and Sr are gener-

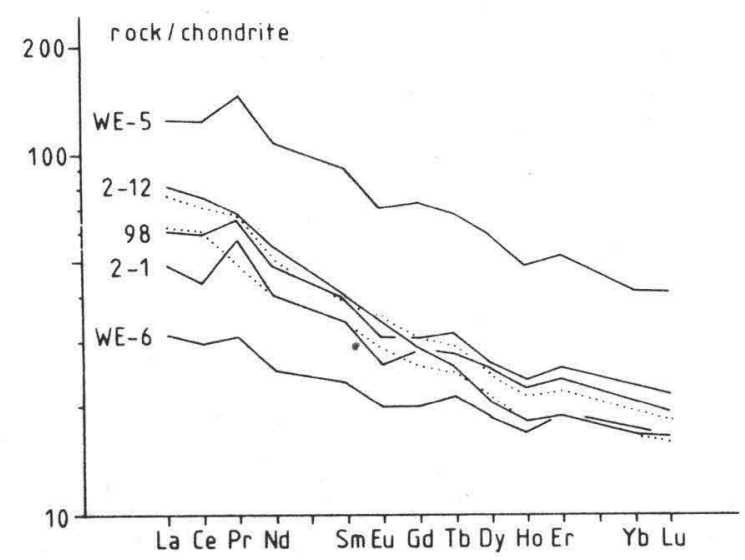

Fig. 9. REE patterns of flaser amphibolites from the Windisch-Eschenbach area compared with the variation of six unaltered flaser amphibolites (dotted lines). ally depleted relative to the unaffected flaser amphibolites. The depletion of $\mathrm{Cr}$ and $\mathrm{Ni}$ is most conspicuous. Moreover, the granite intrusion obviously influenced those trace elements which are commonly regarded as immobile and which are therefore frequently used for discriminations. The contents of $\mathrm{Nb}, \mathrm{Ce}, \mathrm{P}, \mathrm{Zr}, \mathrm{Ti}$ and $\mathrm{V}$ scatter in a much wider range than in the unaffected flaser amphibolites, although with no clear tendency for enrichment or depletion (Fig. 8).

Figure 9 shows REE patterns of flaser amphibolites overprinted by contact metamorphism. The patterns of samples WE-6, 2-1, 98 and 2-12 scatter around those of the unaffected flaser amphibolites, with a stronger variation in the LREE's, especially in $\mathrm{La}$ and $\mathrm{Ce}$. Interestingly, the $\mathrm{La}$ and $\mathrm{Ce}$ contents are correlated with $\mathrm{P}$, with $r=0.97$ for $\mathrm{La}$ and 0.96 for Ce (Fig. 10). The variation of these elements is probably caused by a younger, post-granitic hydrothermal influence (see below).

Only sample WE-5, a metabasite infiltrated by tiny granitic veins, is markedly enriched in all REE's and does not show the La-P and Ce-P correlations. We assume that this amphibolite obtained additional REE's from the granite magma.

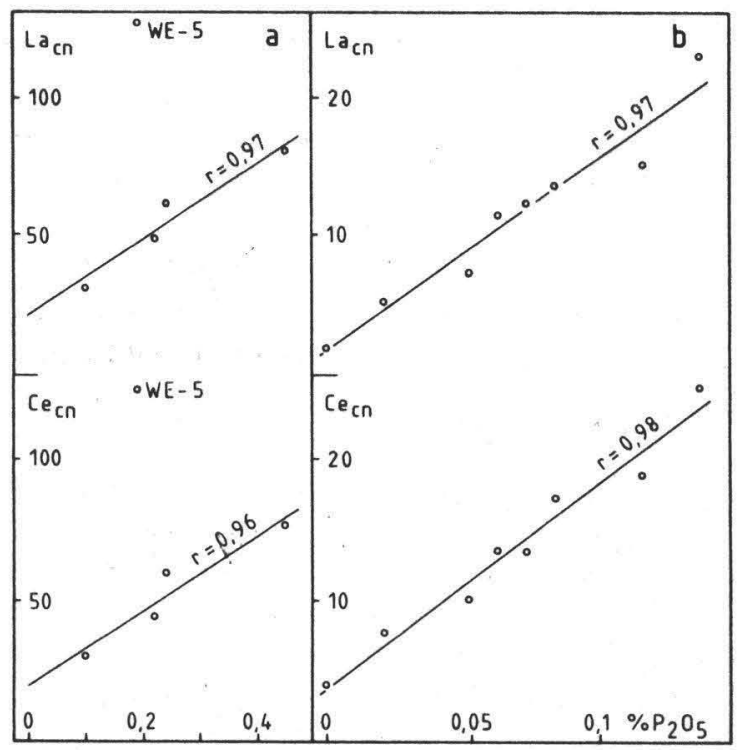

Fig. 10. Correlation between $\mathrm{P}_{2} \mathrm{O}_{5}$ and chondrite-normalized LREE's as demonstrated by $\mathrm{La}$ and $\mathrm{Ce}$. a. Flaser amphibolites from the Windisch-Eschenbach area. b. Schistose and striped amphibolites. 
According to Richter and Stettner (1987), the Falkenberg granite near Windisch-Eschenbach contains between 62 and 180 ppm Ce.

A marked enrichment of the granitophile elements $\mathrm{K}, \mathrm{Rb}, \mathrm{Li}, \mathrm{Sn}, \mathrm{W}$, and $\mathrm{F}$ is recorded in amphibolites from the Roggenstein drill hole close to the western margin of the Leuchtenberg granite in the southern ZEV.

In contrast, contact metamorphism of schistose and striped amphibolites from the Steinach aureole on the southeastern margin of the Leuchtenberg granite did not cause extensive element mobilization. Exceptions, however, are $\mathrm{Cr}$ and $\mathrm{Ni}$ which are markedly depleted, and $\mathrm{SiO}_{2}$ which is enriched from about $48 \%$ (unaffected amphibolites) to 52.5-56.5\%.

Mobilization of $P$ and the lanthanides $-a$ result of hydrothermal alteration

The schistose and striped amphibolites of the ZEV show a wide range of more-or-less depleted LREE and P contents (Figs. 5a and 7a). Judging from the good correlation of $P$ and the LREE's (Fig. 10), this depletion should be due to the same fractionating process. Such a process must involve apatite, the only phosphate mineral found in the metabasites, as apatite contains a large proportion of the LREE's in the whole rock, especially in rocks of basic compositions (cf. Clark, 1984; Nash, 1984).

Although we cannot completely exclude fractionation of apatite during an early stage of crystallization of the basaltic protolith, we assume that the depletion of P and LREE's was caused by decomposition of apatite during post-basaltic alteration processes. This is sustained by the following considerations:

(1) Apatite is not very acid resistant. According to Tröger (1969) apatite-dissolves, for example, in $1 N \mathrm{HCl}$ at room temperature. Thus, it might be affected by acid hydrothermal solutions. Humphris et al. (1978) reported decomposition of apatite and removal of LREE's by secondary alteration of basalts.

(2) Phosphorous mobility during alteration of basic rocks has been demonstrated by various authors (e.g., Hart, 1970; Greenough and Papezik, 1985).

(3) Secondary REE mobilization has been demonstrated (e.g., Hellman et al., 1979; Humphris, 1984)

(4) REE transport is possible in $\mathrm{CO}_{2}$-rich fluids (Hanson, 1980), but also by means of complexes such as (REE) $(\mathrm{Cl}, \mathrm{F})_{2}^{+}$, (REE) $(\mathrm{Cl}, \mathrm{F})_{3},(\mathrm{REE})$ $\mathrm{F}^{2+}$ or in the forms $\mathrm{NaYF}_{4}$ and $\mathrm{Na}_{5} \mathrm{Ce}_{3} \mathrm{~F}_{14}$ (cf. Humphris, 1984). Judging from the excellent correlation of the LREE's with $\mathrm{P}$, a REE transport by the formation of phosphate complexes seems to be an additional possibility. According to Herms (1987), such a process took place during alteration of gneisses by infiltration metasomatism in the Precambrian basement of Finland.

Thus, $\mathrm{P}$ and LREE depletion in some schistose and striped amphibolites of the ZEV can be interpreted as a post-basaltic alteration process which led to the decomposition of apatite and a transport of its chemical constituents by circulating fluids. The timing of this process (pre-, syn- or post-metamorphic) is difficult to assess. However, there are indications that the alteration is related to the post-granitic hydrothermal mineralization (Richter and Stettner, 1987).

In many occurrences the schistose and striped amphibolites and the flaser amphibolites of the ZEV are penetrated by small, post-metamorphic veins in which the primary minerals are replaced by secondary minerals such as sericite, epidote and calcite, or by fine-grained brown minerals. The adjacent minerals are corroded and grain boundaries in the vicinity of hydrothermal veins are stained by limonitic residues. In striped amphibolites, the veins predominantly follow plagioclase-rich or calcsilicate bands. In some veins secondary apatite indicates that this mineral was subjected to post-metamorphic hydrothermal mobilization processes.

The widespread occurrence of hydrothermal veins in metabasites of the ZEV demonstrates that hydrothermal activity was independent of the granite contacts. We assume that mobilization of LREE's and $\mathrm{P}$ in some schistose and striped amphibolites outside the contact zones as well as in contact-metamorphosed flaser amphibolites near Windisch-Eschenbach is a result of this 
post-metamorphic hydrothermal activity which may be directly comparable with the post-granitic hydrothermal event of Richter and Stettner (1987).

This assumption is corroborated by a marked enrichment of As in some of the investigated amphibolites: Richter and Stettner (1987) have shown that in the northern ZEV, As (in part with $\mathrm{Cu}, \mathrm{Zn}, \mathrm{Pb}, \mathrm{U}$ and $\mathrm{F}$ ) is enriched along $\mathrm{NW}-\mathrm{SE}$ trending fault and vein zones which cut the metamorphic sequences and the Variscan granites and which were the supply channels for the hydrothermal fluids. Consequently, As can be regarded as a pathfinder element for the post-granitic hydrothermal alteration. In the region of WindischEschenbach an overlap between the granitic contact aureole and the post-granitic fault and vein zones can be observed.

\section{The behaviour of $\mathrm{Ba}$}

The $\mathrm{Ba}$ contents in flaser amphibolites of the northern ZEV range from 126 to $532 \mathrm{ppm}$ (Table 1). This is higher than expected bearing in mind the tholeiitic E-MORB character of these amphibolites. The same enrichment is true for the schistose and striped amphibolites of the southern ZEV and the ZTM: Ba contents of 38 to $132 \mathrm{ppm}$ are clearly in excess of the average N-MORB content of $20 \mathrm{ppm}$ (Pearce, 1979). A relative enrichment of $\mathrm{Ba}$ in amphibolites of subalkaline geochemical character is frequently observed in various regions. There are two possible explanations:

(1) The Ba was enriched by a pre-metamorphic alteration process involving the interaction of hydrothermal solutions with the basaltic protolith, i.e., around hydrothermal vents on the ocean floor. High $\mathrm{Ba}$ concentrations are known from stratiform sulphide mineralizations. Accordingly, sulphide-rich layers in metabasites of the Roggenstein drillhole show the highest $\mathrm{Ba}$ contents of the investigated metabasites (Table 1).

(2) A second possibility is a $\mathrm{Ba}$ exchange between pelitic sediments and the intercalated basalts during regional metamorphism. The average $\mathrm{Ba}$ content in shales and clays is 800 ppm (Vinogradov, 1962), and in deep-sea clays it is $2300 \mathrm{ppm}$ (Turekian and Wedepohl, 1961). Metapelites of the northern ZEV contain 400-700 ppm Ba
(Richter, unpubl.). During regional metamorphism, both pelitic and basaltic rocks are in contact with a supercritical aqueous fluid which may act as a solvent and transport medium. Only a small amount of $\mathrm{Ba}$ would have to be extracted from the predominant (meta-) pelitic country rocks to raise the $\mathrm{Ba}$ content in the intercalated (meta-) basalts to the observed levels. However, a similar behaviour is barely apparent for $\mathrm{K}$ and $\mathrm{Rb}$ which, too, are enriched in the metapelites and, judging from their similar ionic potential, should have a solubility similar to that of $\mathrm{Ba}$.

\section{Conclusions}

The geochemical investigation of metabasite intercalations within the Erbendorf-Vohenstrauss Zone (ZEV), the Erbendorf Greenschist Zone (EGZ), the Tirschenreuth-Mähring Zone (ZTM) and the Fichtelgebirge area has led to a classification of different metabasite types.

The tholeiitic to calcalkaline metabasites of the EGZ differ clearly from the amphibolites of the neighbouring units: The flaser amphibolites of the northern ZEV show an enriched tholeiitic, EMORB-like character, while the amphibolites of the Fichtelgebirge are similar to enriched tholeiitic to alkaline basalts. These differences emphasize the position of the EGZ as a separate geological unit, possibly a nappe unit, between the Fichtelnaab Fault in the south and the Erbendorf Line in the north.

The schistose and striped amphibolites which are concentrated in the southern ZEV and protrude, in a small band, into the northern $\mathrm{ZEV}$ (Fig. 2), show a N-MORB-like character. Similar amphibolite compositions were recorded in the ZTM. The metagabbros in the southern ZEV have a slightly enriched transitional character, except for some, more primitive samples.

The regional distribution of the different metabasite types in the ZEV may reflect a stratigraphical sequence (Stettner, pers. commun., 1983) extensively deformed to a schuppen structure or to large-scale isoclinal folds with NE-vergence (Hirschmann, pers. commun., 1987).

The geochemical characteristics of the various metabasite types may be used as indicators of the 
wald-Granits nördlich von Erbendorf in der bayerischen Oberpfalz. Neues Jahrb. Mineral. Abh., 82: 1-92.

Mielke, H., Blümel, P. and Langer, K., 1979. Regional lowpressure metamorphism of low and medium grade in metapelites and -psammites of the Fichtelgebirge area, NE-Bavaria. Neues Jahrb. Mineral. Abh., 137: 83-112.

Miyashiro, A., 1975. Classification, characteristics and origin of ophiolites. J. Geol., 83: 249-281.

Nash, W.P., 1984. Phosphate minerals in terrestrial igneous and metamorphic rocks. In: O.J. Nriagu and P.B. Moore (Editors), Phosphate Minerals. Springer, Berlin, pp. 215-241.

Nicholls, I.A., Whitford, D.J., Harris, K.L. and Taylor, S.R., 1980. Variation in the geochemistry of mantle sources for tholeiitic and calc-alkaline mafic magmas, Western Sunda volcanic arc, Indonesia. Chem. Geol., 30: 177-199.

Okrusch, M., 1969. Die Gneishornfelse um Steinach in der Oberpfalz. Eine phasenpetrologische Analyse. Contrib. Mineral. Petrol., 22: 32-72.

Pearce, J.A., 1979. Geochemical evidence for the genesis and eruptive setting of lavas from Tethyan ophiolites. In: Ophiolites. Proc. Int. Ophiolite Symp. (Cyprus, 1979). Geol. Surv. Dep., Nicosia, pp. 261-272.

Pearce, J.A., 1982. Trace element characteristics of lavas from destructive plate boundaries. In: R.S. Thorpe (Editor), Andesites. Wiley, New York, pp. 525-548

Pearce, J.A. and Cann, J.R., 1973. Tectonic setting of basic volcanic rocks determined using trace element analyses. Earth Planet. Sci. Lett., 19: 290-300.

Richter, P., 1983. Geochemie präkambrischer Amphibolite der Grenzzone Saxothuringikum-Moldanubikum NO-Bayerns. In: W. Franke and K. Weber (Editors), Kontinentales Tiefbohrprogramm der Bundesrepublik Deutschland, Zielgebiet Oberpfalz. Univ. Göttingen, Statusber., pp. 68-71.

Richter, P., 1984. Wolfram in Graniten Ostbayerns-Versuch einer metallogenetischen Gliederung. Geol. Jahrb., Reihe D, 63: 3-22.

Richter, P. and Stettner, G., 1983. Das Präkambrium am Nordrand der Moldanubischen Region im Raum Tirschenreuth-Mähring (NE-Bayern) und dessen metallogenetische Aspekte. Geol. Jahrb., Reihe D, 61: 23-91.

Richter, P. and Stettner, G., 1987. Die Granite des Steinwaldes (Nordost-Bayern)-ihre petrographische und geochemische Differenzierung. Geol. Jahrb., Reihe D, 86: 3-31.

Saunders, A.D., 1984. The rare earth element characteristics of igneous rocks from the ocean basins. In: P.L. Henderson
(Editor), Rare Earth Element Geochemistry. Elsevier, Amsterdam, pp. 205-237.

Schreyer, W., 1966. Metamorpher Übergang Saxothuringikum-Moldanubikum östlich Tirschenreuth/Oberpfalz, nachgewiesen durch phasenpetrologische Analyse. Geol. Rundsch., 55: 491-509.

Schüssler, U., 1987. Petrographie, Geochemie und Metamorphosealter von Metabsiten im KTB-Zielgebiet Oberpfalz, Ost-bayern. Dissert., Univ. Würzburg.

Schüssler, U., Oppermann, U., Kreuzer, H., Seidel, E. Okrusch, M., Lenz, K.-L. and Raschka, H., 1986. Zur Altersstellung des ostbayerischen Kristallins. Ergebnisse neuer K-ArDatierungen. Geol. Bavarica, 89: 21-47.

Stettner, G., 1975. Zur geologisch-tektonischen Entwicklung des Oberpfälzer Grundgebirges. Aufschluss, 26: 11-38.

Stettner, G., 1980. Zum geologischen Aufbau des Fichtelgebirges. Auschluss, 31: 391-403.

Teufel, S., 1988. Vergleichende U-Pb- und Rb-Sr- Altersbestimmungen an Gesteinen des Übergangsbereichs Saxothuringikum/Moldanubikum, NE-Bayern. Göttinger Arb. Geol. Paläontol., 35: 1-87.

Tröger, W.E., 1969. Optische Bestimmung der gesteinbildenden Minerale. Schweizerbart, Stuttgart, Vol. 2, 822 pp.

Turekian, K.K. and Wedepohl, K.-H., 1961. Distribution of the elements in some major units of the earth's crust. Bull. Geol. Soc. Am., 72: 172-202.

Vinogradov, A.P., 1962. Die Durchschnittsgehalte der chemischen Elemente in den Hauptarten der Eruptivgesteine. Geochimija, 7: 555-571 (in Russian).

Voll, G., 1960. Stoff, Bau und Alter der Grenzzone Moldanubikum/Saxothuringikum in Bayern unter besonderer Berücksichtiging gabbroider, amphibolitischer und kalksilikatführender Gesteine. Geol. Jahrb, Beih, 42: 1-382.

Weber, K. and Vollbrecht, A., 1986. Kontinentales Tiefbohrprogramm der Bundesrepublik Deutschland, КTBErgebnisse der Vorerkundungsarbeiten, Lokation Oberpfalz. KTB-Kolloq., 2nd (Seeheim, Odenwald 19-21 September, 1986). 186 pp.

Wendt, I., Kreuzer, H., Müller, P. and Schmid, H., 1986. Gesamtgesteins- und Mineraldatierungen des Falkenberger Granits. Geol. Jahrb., Reihe E, 24: 5-66.

Whitford, D.J., Nicholls, J.A. and Taylor, S.R., 1979. Spatial variations in the geochemistry of Quarternary lavas across the Sunda arc in Java and Bali. Contrib. Mineral. Petrol., 70: $341-356$. 